\title{
The Influence of Conflict Management Styles on Leadership Approaches within Small-scale Businesses in Kenya
}

\author{
Catherine Kathure Kaimenyi \\ Department of Business Administration, Chuka University, Kenya
}

\begin{abstract}
This study aims to establish the relationship between conflict management styles of business owners/managers of small businesses and the leadership approaches employed. Through purposive sampling, a sample of 68 participants from the small business community in Kajiado County was used to determine differences in conflict management styles and the leadership styles related to them. Rahim Organizational Inventory (ROC II) instrument was employed to examine the conflict management styles while another instrument was developed to assess the applied leadership style. Results indicated a relationship between conflict management styles and leadership styles.
\end{abstract}

Key words: Conflict management, leadership styles, small businesses

\section{Introduction}

The conservative approach to conflict follows the belief that all conflict is negative and destructive, and as such should be avoided (Rahim, 1992). The avoidance of conflict thus shifts the focus from managing it to trying to prevent it from occurring. As the subject continued to evolve, new approaches to conflict developed, for example, the human relations approach emanating from the studies of Elton Mayo during the 1920s which considered conflict as a natural phenomenon (Robbins 1998).

This paper adopts the conflict style approaches used by Thomas $(1976,1988,1992)$ and Thomas and Kilmann (2002), as well as other frameworks derived from the works of Blake and Mouton (1964). Briefly, conflict involves a situation in which people's concerns appear to be incompatible. In that situation, intentions can be described along two independent Dimensions - cooperativeness (attempting to satisfy the other's concern) and assertiveness (attempting to satisfy one's own concern). Five conflict styles are defined in terms of those dimensions. Competing (low cooperativeness, high assertiveness) is the attempt to satisfy one's own concern at the other's expense. Its opposite is accommodating (high cooperativeness, low assertiveness), which sacrifices one's own concern in favor of the other's. Avoiding (low cooperativeness, low assertiveness) neglects both people's concerns by sidestepping or postponing a conflict issue. Collaborating (high cooperativeness, high assertiveness) is an attempt to find an integrative or win/win solution that fully satisfies both people's concerns. Finally, compromising (intermediate in both cooperativeness and assertiveness) is an attempt to find a middleground settlement that only partially satisfies each person's concern ( Kenneth \& Gail 2008).

Generally, leadership is about inspiring and influencing behaviour of followers. Pierce and Newstrom (2000) argue that leaders influence others through their ability to motivate, inform, inspire, exhibit technical competence, communicate effectively, and convey a vision. Most typically leadership is utilized to influence others towards goal achievement. There are a number of different leadership styles and strategies used to accomplish goals. Among the leadership styles commonly employed are Autocratic (dictatorship and leaders centered), Democratic (participative and subordinate centered), Bureaucratic (rule and structure centered) and Laissez-Faire (care free where leader acts as a consultant). Although no form of leadership encompasses traits that can be applied to all leaders in a uniform manner, Robbins (2007) maintains that drive and ambition, desire to lead, honesty and integrity, self-confidence, intelligence, and in-depth technical knowledge related to ones area of responsibility stands out for effective leaders

\section{Purpose and significance of the Study}

This study analyzes the conflict management styles used by managers in small businesses to and the influence this has on their preferred leadership style.

\section{Research questions}

The exposition of research question is to examine the various methods of conflict management styles employed by business managers/owners, and the relationship of this with the leadership styles exhibited they these managers. Specifically the research addresses the following questions:

1. What conflict management styles are used by managers/owners of small businesses?

2. What is the relationship between conflict management styles with the leadership styles? 


\section{Scope of the study}

The foundation of this study rests upon the interaction among the five variables of Thomas-Kilmann Conflict model (1997). Primary data was collected using survey questionnaire from Kajiado county. Data was analyzed using both qualitative and quantitative approaches to understand the relationship between conflict management styles and leadership approaches.

\section{Literature Review}

This section reviews the interacting relevant constructs and variables involving the concept of conflict, the conflict handling styles and satisfaction with employer's conflict handling style.

\section{The Concept of conflict}

Conflict is generally defined as disagreement with interest or ideas. Wilmont and Hocker (2001) defines conflict as an expressed struggle between at least two interdependent parties who perceive incompatible goals, scarce resources and interference from others in achieving their goals. It is a process in which one party perceives that its interests are being opposed or negatively affected by another party. Antonioni 1999) identified conflict as an interactive process manifested in incompatibility, disagreement or dissonance within or between social entities. It is therefore noted that no single definition of conflict exist, and that perception influences how conflict is viewed in different situations.

There are many classifications about the types of conflict. For example according to Rahim (1986) conflict can occur between individuals, groups, organizations or even nations. Pondy (1976) classifies three conceptual models of conflict. One, the bargaining model where the interest groups are in competition for scarce resources. Two, the systems model which defines conflict among parties in a lateral or functional relationship, and in particular the problems of coordination, and three, the bureaucratic model which describes the type of conflict experienced among superior and subordinates or along any vertical dimension in the organizational hierarchy. This research employs the bureaucratic model in understanding the conflict from the employer employee relationship.

If an individual is perceived to manage conflict in an appropriate and effective manner, that individual is also perceived to be more competent in general (Gross \& Guerrero, 2000). This is because their conflict management approaches tend to leave employees satisfied, and in turn get committed, work hard and relate well to their colleagues.

\section{Conflict Management Styles}

There are various styles of behavior by which interpersonal conflict can be handled. In order to manage conflict effectively, one style may be more suitable than the other depending upon the situation. Follett (1940) conceptualized five methods of handling conflict in organizations i.e. domination, compromise, integration, avoidance and suppression. Blake and Mouton (1964) later modified Follett model with their dual concern model that conflict is managed in different ways (namely withdrawing, smoothing, forcing, problem solving, compromising) based on high/low concern for production and high/low concern for people. Thomas and Kilmann (1974) extended this model by focusing on the desire to satisfy your own concerns and the desire to satisfy the other's concern, what came to be known as Thomas-Kilmann Mode instrument.

\section{Thomas-Kilmann Mode Instrument}

This model assesses an individual's behavior in conflict situation, describing a person's behaviour along two basic dimensions; assertiveness and cooperativeness. Assertiveness describes the extent to which the individual attempts to satisfy his own concerns while cooperativeness shows the degree to which the concern for others takes priority. These two dimensions can be used to define five modes of dealing with conflict; Competing, Collaborating, Compromise, Avoiding and Accommodating.

\section{Avoiding Conflict Handling Style}

This style is associated with both low concern for self and others. It is usually accompanied by withdrawal, because those using it neither satisfies their own or the other party's concern. Avoidance involves suppressing, setting aside ignoring and refusing to address the issues in question. The style is often used when the potential consequences of confronting the other party seem to outweigh the benefit of resolving the conflict, or when the issues in question are minor.

\section{Compromising Conflict Handling Style}

Compromising style is associated with an intermediate level of concern for self and others. This style typically involves "give and take" where both parties involved relinquish some aspect in order to arrive at a 
mutually-acceptable decision. It is often used when the goals of the conflicting parties are mutually exclusive or when both parties, who are equally powerful, such as a labor union and management, have reached a stalemate.

\section{Collaborating Conflict handling style}

This style, also known as integrating or problem solving and is characterized by a high concern both for self and for others. It represents a desire to fully satisfy the needs of both parties. Both parties in conflict are willing to exchange information openly and thoroughly to examine differences constructively and reach an effective mutually accepted situation, thereby creating a win-win scenario. Collaborating style is both effective and appropriate in managing conflicts.

\section{Accommodating Conflict Handling Style}

The style is also called smoothing or obliging. It indicates a low concern for self and high concern for others. Individuals using the style tend to satisfy the needs of others while ignoring or sacrificing their own needs. It is thus non-confrontational associated with playing down differences and focusing on relationships, cooperation and harmony, and therefore putting aside one's needs to please the other party in a conflict situation. (Wilmot \& Hocker, 2001).

\section{Competing Conflict handling style}

Competing style, also labeled dominating expresses high concern for self and low concern for others, meaning the individual pursues goals at the other party's expense. The style is also known as forcing or imposing because it aims at wining and ensuring the other party loses through use of position power, aggression and verbal dominance.

\section{Leadership styles}

Leadership style plays an important role in shaping the behaviour and attitudes of employees in and organization. Reinke (2009) identifies four leadership styles and stresses that each style has a fundamental foundation and that most leaders practice some form of leadership or a combination of styles during their normal work routine.

\section{Autocratic Leadership Style}

Autocratic leaders limit self-determination and autonomy and push followers to accept the their ideas. Such leadership decrease subordinates sense of control and goal striving and increase powerlessness. Autocratic leaders are in complete control as they push their followers to conform to their image. They leave little room for free thought. Although not a popular approach to leadership there are situations when it is most suitable, for when an organization is in a crisis and followers require clear and concise direction.

\section{Bureaucratic Leadership Style}

Bureaucratic Leadership style is commonly defined as one that emphasizes procedures. It is the use of rules, policies, hierarchy of authority, written documentation, standardization, and other bureaucratic mechanisms to standardize behavior and assess performance (Brian 2006). Bureaucratic leaders are motivated by the need to control through documentation. Followers are merely instruments used to create bureaucracy within the organization as well as understand the procedures they write. Bureaucratic leaders produce followers that do only what is expected and nothing more. (Reinke 2009)

\section{Democratic Leadership Style}

Democratic leadership style has been called a participative style because it suggests that leaders allow followers to participate in the management process. There are times when allowing followers to participate in management decisions can cause some democratic leaders to fear losing control. Richard (2001) suggests in democratic leadership, the role of the leader is not just solving problems but more importantly is to identify the conditions for effective solutions. Democratic leaders are motivated by highly skilled and experienced employees who are not afraid to express their opinions.

\section{Laissez-Faire Leadership Style}

Laissez-faire leaders are those who avoid their assigned managerial duties. This includes behavior such as failing to initiate any structure for their employees, making no effort to show any consideration for their workers well being, failing to communicate performance expectations to employees, failing to hold employees accountable, and making no effort to maintain motivation and morale Reinke 2009. Many leaders who practice this style of leadership are inclined to allow their followers freedom to solve important issues on their own. Laissez- faire leaders surround themselves with highly skilled, experienced, and educated followers that are 
capable of working un-supervised. Laissez-fair leaders are satisfied with their position and need only perform well enough to keep their status in the organization.

\section{Population and Sampling Design}

\section{Research Methodology}

The study was conducted in Kajiado County, selecting 68 respondents through purposive sampling methodology. This involved identifying and approaching a member of the relevant population within the smallscale business sector. The survey further utilized snow-ball sampling techniques to identify respondents who easily introduced the researcher to other respondents.

\section{Research Instruments}

Questionnaires were designed to collect primary data. Conflict management styles were measured using 28 items from Rahim Organizational Conflict Inventory - II (ROCI-II: Rahim 1983). Using a 5-point Likert scale, the conflict management styles were examined. Another instrument comprising of 18 items was developed to identify leadership styles applied by small business managers.

\section{Study Design}

A survey design was chosen for this study. The survey methodology was chosen because it provided the means to collect data rapidly and effectively from the scattered populations in the informal setting. The samples were drawn from amongst individual who were owners/manager of small businesses. Quantitative data was cleaned, coded, analyzed and interpreted using the Statistical Package for Social Scientists (SPSS). Simple descriptive statistics were then utilized to organize, summarize, present, and interpret the finding of the study.

\section{Findings and Discussions}

A total of 73 responses were received of which 68 were usable. Thirty five respondents were female while the number of male respondents was 33 . In establishing the number of employees under each category, $15 \%$ of the were in charge of over 8 employees, $20 \%$ commanded between 4 to 8 employees, $50 \%$ had 2 to 3 subordinates while $15 \%$ had one employee. In terms of age, the highest proportion of managers $(45 \% \%)$ fell into the $20-30$ years age group, followed by $28 . \%$ in the age category of $31-40$. Those in the age bracket of $41-50$ accounted for $20 \%$ and only $7 \%$ were above 50 .

Majority of the male respondents (65\%) used competing style of conflict management compared to $34 \%$ of their women counterparts. $20 \%$ of the male respondents used compromising style, $11 \%$ used collaborating, 9\% used accommodating and only 5\% used Avoidance style. Although at a far much lower rating, Collaborating style emerged the most used by female respondents $(40 \%)$, compromising was rated at $20 \%$, competing style at $18 \%$, avoidance at $12 \%$ and accommodating at $10 \%$. As regards the age brackets those between 20 to 30 years were more inclined to competing style (75\%) compared to those over 50 whose preference to competing style stood at $59 \%$. For female respondents, the use of the preferred conflict handling style had no significant variation in terms of age, where those between 20 to 30 preference for compromising style stood at $42 \%$ as opposed to $39 \%$ from the over 50 in preference for the same style.

In relation to leadership style, majority of the male respondents $(78 \%)$ were inclined to autocratic leadership against $32 \%$ of the female respondents who used autocratic leadership. The most preferred style utilized by female respondents was collaborative $(69 \%)$. In relation to preferred leadership style, the highest utilized style by male respondents was Autocratic $(70 \%)$ while for women it was democratic leadership with $65 \%$ rating. Only $08 \%$ of the total respondents used bureaucratic form of leadership.

\section{Conclusion}

This study provides insights into conflict management styles and their relationship with leadership styles applied by managers of small business. More so relationships in terms of gender and age have been revealed. In some cases, the results are consistent with other studies. It has emerged that females use collaborating styles more frequently compared to males. It is also evident that age has little influence on the conflict handling style that females use. According to Sorenson (1994) businesses that produce the highest outcomes have developed a norm of collaborating, which puts women at a better competitive position in business. On the other hand results have revealed that males use competing styles more frequently compared to female and that age significantly influence the preferred style. Younger males use competing style more commonly than the older males. Competing style of conflict management seemed to be closely related with autocratic leadership style, drawing a conclusion that men are more likely than women to apply autocratic leadership as a result of their conflict management style. On the other hand women appeared to use democratic leadership which is closely related to their collaborating conflict management style. This situation is in 
agreement with the view of Gary (2008) who argued that male bosses were much more severe than the women, and were three times as likely to suspend or sack a subordinate without consultation.

\section{References}

[1]. Antonioni, D. (1999). Relationship between the Big Five Personality Factors and Conflict Management Styles. International Journal of Conflict Management, 9(4): 336-355.

[2]. Armstrong, M. (2003). A Handbook of Human Resource Management Practice. (9thed.). London: Kogan Page

[3]. Blake, R.R. and Mouton, J.S. (1964). The Managerial Grid. Houston, Texas: Gulf Publishing Co.

[4]. Brian, S. (2006). Thoughts on Leadership, Certification magazine. http://0-web.ebscohost.com

[5]. Follett, M.P. (1940). Constructive Conflict. In H.C. Metcalf and L. Urwick (Eds.), Dynamic Administration: The collected papers of Mary Parker Follet (pp. 1-20), New York: Harper

[6]. Gary, Y. (2008). Leadership in Organisations. $6^{\text {th }}$ Edition. Prentice Hall: India

[7]. Gross, M. A., \& Guerrero, L. K. (2000). Managing conflict appropriately and effectively: An application of the competence model to Rahim's organizational conflict styles. The International Journal of Conflict Management, 11(3), 200-226.

[8]. Kenneth, W.T., \& Gail, F.T. (2008). Conflict styles of Men and Women at Six Organization Levels, International Journal of Conflict management, 14(2), 1- 38

[9]. Kilmann, Ralph; Kenneth W. Thomas (1977). "Developing a Forced-Choice Measure of Conflict-Handling Behavior: The "MODE" Instrument". Educational and Psychological Measurement volume 37 issue 2: 309-325. doi:10.1177/001316447703700204

[10]. Locke, E.A. (1976). The nature and cause of job satisfaction. In M. D. Dunnette (ed.). Handbook of Industrial and Organizational Psychology. Chicago: Rand McNally

[11]. Pondy, L.R. (1976). Organizational conflict: Concepts and models, Administrative Science Quarterly, Vol. 12, pp.296-320

[12]. Rahim, M.A. (1986). Referent Role and Styles of Handling Interpersonal Conflict. Journal of Social Psychology,126: 79-86.

[13]. Reinke, D.A. (2009). Leadership styles and motivation through the Eyes of the follower. http://www.leadingtoday.org/Onmag/2009\%20Archives/December\%2009/dr-december09.pdf

[14]. Richard, A. (2001). Democratic Approaches to Change: Make a Big Difference in Turbulent Times. Harvard Management Update. http://0-web.ebscohost.com

[15]. Robbins S., \& Judge, T. (2007). Organizational Behaviour $12^{\text {th }}$ Edition Prentice Hall: New Delhi

[16]. Sager, F.K. (1994). The Role of Behavior Intentions in Turnover of Salespeople. Journal of Business Research,29(3): 179-189.

[17]. Thomas, K. W., \& Kilmann, R. H. (1974). Thomas-Kilmann Conflict Mode Instrument, Consulting Psychologists Press, Palo Alto, CA.

[18]. Wilmot, W. W., \& Hocker, J. L. (2001). Interpersonal conflict. New York, NY:McGraw-Hill 